\title{
BASALT FIBER BASED BIOCIDE MATERIALS
}

\author{
V.M. Shevchenko ${ }^{1}$, N.A. Guts ${ }^{1}$, A.Ye. Shpak ${ }^{1}$, E. R. Surovtseva ${ }^{2}$ \\ ${ }^{1}$ National Technical University of Ukraine “KPI named Igor Sikorsky”, \\ 03056, Kyiv, Peremogyav., 37, (+38044)236-97-74, e-mail: gutsanelya@ukr.net \\ ${ }^{2}$ Institute of Semiconductor Physics of the National Academy of Sciences of Ukraine, \\ 03028, Kyiv, Science av., 41, (093)252-27-45, e-mail: info@isp.kiev.ua
}

It has long been known that materials containing cellulose fibers in their composition are destroyed by molds, microorganisms, actinomycetes, which use cellulose as a carbon source.

Different fibrous materials to varying degrees (but always) are affected by molds. It is known that linseed and cotton types of paper are affected by the smallest number of fungi, and sulphate ones by the largest. The most biostable is cotton paper, the composition of which contains chalk in a sufficiently large amount. The observations carried out by the authors showed that the highest biostability (fungal resistance) is characteristic of papers containing chalk and kaolin, the lowest is glued types of paper with a high degree of sizing. Aging of paper with increasing temperature increases the overall susceptibility of all types of paper tested without exception. Obviously, changes in the physical and chemical properties of paper as a result of aging create more favorable conditions for the growth of fungi. It is well known that paper can serve as a medium for the spread of infectious diseases. The authors of the article studied the thermo-physical properties of basalt fiber and investigated the possibility of using it for the manufacture of heat-insulating technical paper.Obtaining materials that are not affected by bacteria, insects and molds (fungicidal,insecticidal) can be solved by using inorganic fibers, which are obtained from almost unlimited natural resources and which have excellent biochemical properties. It should be noted that the concept of "biocidal" paper (material) is collective. It combines species that differ in their ability to kill bacteria (bactericidal), molds (fungicidal), insects (insecticidal). Each of the biocidal types of materials has two or more of these properties.

Keywords: biostable material, cellulose, basalt fibers, clay minerals.

\section{Introduction}

It's long been known that materials which contain cellulose fibers in their composition are subject for destruction by mold fungi, microorganisms, actinomycete bacteria which use the cellulose as a source of carbon.

Different fibrous materials to varying degrees, but are necessarily affected by molds. It is known that the smallest number of fungi affect linseed and cotton types of paper (almost equally), and the largest - sulfate ones.

The most biostable is cotton paper, the composition of which contains chalk in a sufficiently large amount.

Observations carried out [1] have shown that paper containing chalk and kaolin in addition to fibers is distinguished by the highest resistance to fungi. The least resistant paper is the glued paper with the highest degree of sizing. Aging of paper at elevated temperatures increases the overall susceptibility of all types of paper tested without exception. Obviously, changes in the physical and 
chemical properties of paper as a result of aging create more favorable conditions for the growth of fungi.

O.V. Kozulina et al. [1] revealed the "tastes" of book pests: these fungi prefer cotton and sulphate paper, and have a negative attitude towards paper with rosin sizing and fillers such as chalk, kaolin and others.

It is well known that paper can serve as a medium for the spread of infectious diseases [1]. We may obtain materials that do not fall under the action of (fungicidal, insecticidal) bacteria, insects, and mold by using inorganic fibers. Those fibers are obtained from almost unlimited natural resources. They are non-toxic, have excellent biochemical characteristics, high thermal stability and low thermal conductivity. Such is the material based on the use of basalt fiber in its composition. Shrinkage depends on the initial bulk density of basalt wool: the greater the bulk density, the higher the temperature at which shrinkage begins. Thus, the temperature of the onset of inelastic deformation of basalt fibers is $500-700{ }^{\circ} \mathrm{C}$, depending on the bulk density, and that of glass fiber $\mathrm{STV}$ is $400^{\circ} \mathrm{C}$.

Of the technical types of biocidal paper, first of all, cable paper should be mentioned, which serves to insulate an electric cable that is laid in moist soil. However, the task of making such paper is not straightforward.

All types of paper that are used in such applications must meet the proper requirements.

It should be noted that the term "biocidal" material (paper) is a general definition. It combines various types that have the ability to kill bacteria (bactericidal), molds (fungicidal), insects (insecticidal) having mentioned special properties.

One of the main purposes of this type of paper is the packaging of various types of food products intended for long-term storage (butter, margarine, cheese, meat, etc.). Fungicidal properties are required for paper used for packaging and long-term storage of fruits and vegetables, as well as for cardboard used for the same purposes.

In this regard, clay minerals [1] such as palygorskites and montmorillonites from Ukrainian mines have proven themselves well.

\section{Experimental part}

To obtain a coarser material of specified compositions, the method of recharging one of the contacting phases was used, for example, treating basalt fibers with a solution of a cationic reagent (aluminum sulfate), which changes the sign and magnitude of the surface charge. Data is shown in Table 1.

Table 1. Physical and mechanical properties of compositions consisted of basalt and cellulose fibers

\begin{tabular}{|l|l|l|l|l|}
\hline Cellulose content, \% & \multicolumn{2}{|l|}{ Original basalt fiber } & \multicolumn{2}{l|}{ Recharged basalt fiber } \\
\hline & Break, r.g.u. & Breaking length,m & Break, r.g.u. & $\begin{array}{l}\text { Breaking } \\
\text { length,m }\end{array}$ \\
\hline 30 & 252 & 654 & 314 & 766 \\
\hline 70 & 486 & 836 & 618 & 892 \\
\hline
\end{tabular}

The materials were tested for biostability regarding to certain types of fungi and microorganisms. It is known that performance indicators relate primarily to cellulosic components, because basalt and other components do not stimulate, but inhibit the destruction of materials and the growth of fungi and microorganisms. The study of samples for biostability was carried out both on pure cultures and on mixtures of fungi. 
Obtaining a thin, strong, flexible material from basalt fiber is problematic, because it has no paper-forming properties. Therefore, various kinds of binders are used, which give the finished material strength, while not impairing their properties.

There are many ways to impart biocidal properties to materials by adding the required reagents to the composite. Organic acids are often used, such as salicylic, sorbic, and even arsenic, etc. But most of them have a significant drawback - they are toxic.

From all points of view, the best option for products of different nature is a composition consisting of fibers of inorganic nature - it's non-toxic, durable, obtained from practically unlimited natural resources, with excellent technical characteristics and high thermal stability.

Staple basalt fiber with a diameter of $7-12$ microns is produced by the blowing method, which differs from the method of manufacturing continuous fiber in that the fiber is drawn not mechanically using a rotating drum, but by a compressed air stream. In this case, the fiber is stretched due to the action of frictional forces between the air flow and the fiber moving at different speeds. It is believed that with this method, along with the stretching of the mass, its dismemberment occurs.

Ultra-thin and super-thin basalt fiber with a diameter of $0.5-2.5$ microns is produced by a method based on a duplex process. In the first stage of the process, continuous primary fibers with a diameter of 150 - 200 microns are drawn from the spinnerets of the melting vessel at a speed of 6 $\mathrm{m} / \mathrm{min}$. In the second stage, the primary fibers are fed by a pulling device to the combustion chamber nozzle, where they soften under the action of a high-temperature flow of combustible gases, split into small pieces and blown into the finest fibers.

The authors of the article studied the thermo-physical properties of basalt fiber and investigated the possibility of using it for the manufacture of heat-insulating technical paper.

Table 2. Biocidal content of materials containing recharged basalt fiber, cellulose fiber: $15 \%$ montmorillonite treated with a peptizer $0.15 \%$ (sodium hydroxide solution)

\begin{tabular}{|c|c|c|c|c|c|c|}
\hline Types of molds & \multicolumn{6}{|c|}{ Cellulose fiber content } \\
\hline & \multicolumn{3}{|c|}{$40 \%$ of cellulose fibers } & \multicolumn{3}{|c|}{$50 \%$ of cellulose fibers } \\
\hline $\begin{array}{l}\text { Chactomium } \\
\text { affine }\end{array}$ & 4 & 3 & 4 & 4 & 4 & 5 \\
\hline $\begin{array}{l}\text { Paccilomyces } \\
\text { varyoty }\end{array}$ & 5 & 4 & 4 & 5 & 4 & 5 \\
\hline $\begin{array}{l}\text { Trihoderma } \\
\text { lignorum }\end{array}$ & 4 & 5 & 4 & 5 & 5 & 5 \\
\hline $\begin{array}{l}\text { A mixture of } \\
\text { fungi }\end{array}$ & 6 & 5 & 6 & 5 & 5 & 6 \\
\hline
\end{tabular}

The authors of the article studied the thermo-physical properties of basalt fiber and investigated the possibility of using it for the manufacture of heat-insulating technical paper. Also, we took into account the experience of colleagues described in [3]: after heating to 600 degrees for 3 hours of cooling, the tensile strength of basalt fiber with a diameter of $10-11$ microns is $70 \mathrm{kgf} / \mathrm{m}^{2}$, i.e. retains about $80 \%$ of the original strength. Note that the strength of the best industrial mineral fibers with a diameter of $8-10$ microns is retained only by $50-60 \%$, while for glass fibers with a diameter of 10-11 microns (of the GRP type) it is completely destroyed at the indicated temperature. 
The decrease in the mechanical strength of basalt and glass fibers as a result of heat treatment is a consequence of the formation of a crystalline phase, which can be observed during Xray phase analysis.

It is known that the temperature of the onset of inelastic deformation of basalt fibers is 500 $700{ }^{\circ} \mathrm{C}$ (depending on the bulk density), and for glass STA $-400{ }^{\circ} \mathrm{C}$. At higher temperatures $(600-$ $700{ }^{\circ} \mathrm{C}$ for glass and $1080{ }^{\circ} \mathrm{C}$ for basalt) the fiber is sintered.

A few words about what biostability is. The easiest way to determine biostability is visual. This method is the most common and has several modifications. In the simplest case, the specimens used are moistened, infected with fungi and placed in a warm place. The degree of fungal fouling of the samples is determined "by eye" and is assessed using an arbitrary system [1].

The test pieces of materials can be examined by placing the test material on a solid surface of the medium [2]. This modification of the method has no drawbacks, since the growth of fungi is sometimes observed on the nutrient medium (in the case of using agar with mineral and organic salts). If you use "hungry" agar, moistened with a mineral medium and devoid of easily digestible carbohydrates (poor nutrient medium for fungi), the results will be better, because fungi in this case develop at the expense of the material and the picture of biostability is clearer.

A mineral medium (mineral gel) is obtained by mixing equal volumes of liquid glass and hydrochloric acid [1].

In visual observations, the character of growth on the test material and the degree of fouling of the latter are assessed according to an arbitrarily adopted system. Growth is measured in points.

The method is not without its drawbacks, however, when working with a large set of test materials, a fairly objective picture of their comparative biostability can be presented. It should be noted that this method is widely used to study the biostability of materials made from fibers of various natures of different grades [1].

A more objective method for determining biostability is the strength and service characteristics of the test material. In this case, the test material is contaminated with fungi and at the end of the incubation period its physical, mechanical and filtering characteristics are checked.

The degree of destruction of the material is established by comparing of leached the initial indicators with those obtained. Such a method is widely used [1].

The experimental technique consisted of two parts: visual observation and quantitative accounting of properties.

Three series of experiments were performed: in liquid Van Iterson's medium, on the surface agar (Czapek's medium), and in a humid chamber. 1/4 strips of prototypes of materials $8 \times 8$ sm were immersed in Van Iterson's mineral medium or contacted with the medium and became infected with fungi. The crops were examined weekly for 180 days. Fungus fouling of materials was noted on a 10-point scale, where 10 is the highest degree of fouling. A quantitative account of the destruction of materials was carried out as follows: strips of materials before infection with fungi and after a certain time (from a month to six) were dried to constant weight, washed from plaque and mucus in $1 \%$ sodium solution, and then in water, and after all we tested them for properties. It should be noted that studies of biostability in the Van Iterson mineral environment are very convenient, because experiments are carried out in test tubes, the nature of growth in the system is clearly visible.

\section{Conclusions}

These data make it possible to propose a material and a composition that effectively influences (near stops) the growth of fungi and microorganisms, delays the appearance of mold, reduces the resistance of agglomerate spores, and increases resistance. The greatest effect is 
manifested in the samples that contain basalt fiber with $15 \%$ montmorillonite treated with sodium hydroxide. In addition, it has been proven that materials containing a higher amount of cellulose fiber are the first to be attacked by fungi. The biostability of materials increases with an increase in the percentage of basalt fiber in their composition. The pre-recharging of the basalt fiber results in a stronger and more durable material with improved characteristics.

The biostability of materials increases with increasing percentage of basalt fiber in their composition. Pre-charging the basalt fiber results in a stronger and more durable material with improved performance.

The authors of the article studied the thermo-physical properties of basalt fiber and investigated the possibility of using it for the manufacture of heat-insulating technical paper. From the point of view of paper properties, it is advisable to use fibers with a smaller diameter, because with a decrease in diameter, the thickness decreases and the elasticity increases.

\title{
References
}

1. Flyate D. M., Properties of Paper Edition 3.(Moscow, Forestry, 1986)

2. Kruglitskyi N.N. Physics-chemical bases of regulating properties of the disperse of clay minerals.Kyiv, Naukova dumka, 1994.

3. Biocide basalt compositions //Shevchenko V.M., Guts N.A.//Surface. 2018. 10(25). p.170178

\section{БІОЦИДНІ МАТЕРІАЛИ НА ОСНОВІ БАЗАЛЬТОВОГО ВОЛОКНА}

\author{
В.М. Шевченко ${ }^{1}$, Н.А.Гуц ${ }^{1}$, А.С. Шпак ${ }^{1}$, О. Р. Суровцева ${ }^{2}$ \\ ${ }^{1}$ Національний технічний університет Украӥни «КПI імені Ігоря Сікорського», \\ 03056, м. Киї, пр-m Перемоги, 37, (+38044) 204-97-94, ,e-mail: gutsanelya@ukr.net \\ 2 Інститут фізики напівпровідників Національної Академії Наук Украӥни, \\ 03028, м.Київ, nр-m Науки, 41, (093)252-27-45, e-mail: info@isp.kiev.ua
}

Давно відомо, щуо матеріали, щуо містять у своєму складі волокна цүелюлози, руйнуються пліснявою, мікроорганізмами, актиноміцетами, які використовують целюлозу як джерело вуглецю. Спостереження, проведені авторами, показали, щзо найбільша біостійкість (стійкість до грибків) характерна для паперу, щэо містить крейду та каолін, найменша - клеєний папір з високим ступенем проклейки. Очевидно, щзо зміни фізико-хімічних властивостей паперу в результаті старіння створюють більш сприятливі умови для росту грибів. Отримання матеріалів, не уражених бактеріями, комахами та пліснявою (фунгіциидними, інсектицидними), можна вирішити за допомогою неорганічних волокон. Слід зазначити, щзо поняття «біоцидний» папір (матеріал) є збірним. Він об’єднує види, щзо відрізняються за здатністю знищувати бактерії (бактерицидні), иявілі (фунгіцидні), комах (інсектицидні). Автори запропонували матеріал $i$ композицію, яка ефективно впливає (майже зупиняє) на ріст грибів і мікроорганізмів, затримує появу плісняви, знижує стійкість агломератних спор, підвишує стійкість. Найбільший ефект проявляється у зразків, які містять базальтове волокно з 15\% монтморилонітом, обробленим гідроксидом натрію. Крім того, було доведено, щзо матеріали, щзо містять більшу кількість целюлозного волокна, 
першими піддаються нападу грибків. Біостійкість матеріалів зростає зі збільшенням відсотка базальтового волокна в їх складі. Попередня зарядка базальтового волокна призводить до отримання міџнішого $i$ довговічного матеріалу $з$ покращеною продуктивністю.

Автори статті вивчили теплофізичні властивості базальтового волокна та дослідили можливість його використання для виготовлення теплоізоляційного технічного паперу. 3 точки зору властивостей паперу, доцільно використовувати волокна меншого діаметра, оскільки зі зменшенням діаметра зменшується товщина $i$ підвищується еластичність.

Ключові слова: біоцидні матеріали, целюлоза, базальтові волокна, глинисті мінерали 